\title{
STUDYING THE CHANGES IN THE CHARACTERISTICS OF RADIATION-PROTECTIVE COMPOSITION MATERIALS IN DEPENDENCE ON HOMOGENEITY OF DISTRIBUTING OF METAL COMPONENTS
}

\author{
E.M. Prokhorenko, V.V. Lytvynenko, A.A. Zakharchenko ${ }^{1}$, \\ M.A. Khazhmuradov ${ }^{1}$, T.G. Prokhorenko ${ }^{2}$ \\ Institute of Electrophysics and Radiation Technologies NAS of Ukraine, Kharkov, Ukraine; \\ ${ }^{1}$ NSC “Kharkov Institute of Physics and Technology”, Kharkov, Ukraine; \\ ${ }^{2}$ Kharkov National Automobile and Highway University, Kharkov, Ukraine \\ E-mail:forshad58@gmail.com
}

\begin{abstract}
The dependence of the hardness of polystyrene-metal composite materials on the homogeneity of the distribution of particles of a component over the volume of a composite material is investigated. Improvements are made to thermoplastic-automata, which make it possible to improve the quality of composites production. The methods of IR-radiometric diagnostics of the component mixing efficiency are improved. The speeds of the mixer blades are experimentally determined depending on the size and number of particles of the metal components. Radiation protective characteristics were obtained for composite materials by numerical methods. Analyzed the attenuation of the absorbed dose of ionizing radiation, depending on the energy of gamma-rays.
\end{abstract}

PACS: 81.05.Qk, 87.55K-, 87.55N-

\section{INTRODUCTION}

Much attention is paid to the issues of creating and improvement of radiation-protective materials [1-3]. The reason for this is a change in the approach to radiation safety at nuclear facilities, the radiochemical industry, and medicine. More hard requirements for protection against the radiation effects of biological objects (personnel, population), equipment and installations, the environment. The question of processing and utilization of equipment - sources of ionizing radiation is very acute. The issue of processing and disposal of spent nuclear fuel and nuclear waste has not been resolved [4]. All of it pulls out high requirements to radiation-protective materials [5].

The use of traditional protective materials is not always efficient and cost-effective. Therefore, it is necessary to solve the issue of modifying old radiation protective materials and development of new. One of the promising areas is the development of various composite materials. To do this, it is necessary to solve the problems of developing and creating composite materials, to study of their radiation-protective properties, behavior under irradiation, to the change of structure as a result of influence of ionizing radiation.

\section{PURPOSE OF WORK}

Research of the hardness characteristics of radiationprotective composite materials depending on the composition of components and manufacturing quality. Study of the criticality of the effect on the strength of composite materials of the heterogeneity of the distribution of metal components. Development of methods for IR radiometric control of the composites production process. The study of these questions will determine the admittances on the quality of making.

\section{THE MAIN PART}

The problem of radiation protection includes the solution of issues of protection against the main types of ionization radiation. These are neutron streams, alphaand beta-particles, gamma- and X-rays. To protect against neutrons, you must use light elements B, H, N. $\mathrm{X}$-ray and gamma-radiation is well absorbed by elements with large atomic masses $(\mathrm{Pb}, \mathrm{W}$, etc.).

Thus, the use of one material does not allow for the creation of universal protection. The problem can be solved by creating composite materials. When they are created, materials with different properties are compiled, which makes it possible to obtain a composite with the required characteristics. In our case, the composite material consisted of a connective base and fillers. The creation of radiation-protective composite materials was based on the use of highly dispersed fillers with high radiation-protective properties.

The use of powder materials makes it possible to obtain a composite with a high degree of homogeneity. Depending on the characteristics of the components, the characteristics of the composite material also change. For the basis of the composite material, polystyrene PSM-115 (GOST 20282-86) was taken. For polystyrene, methods of manufacturing various products have been developed. Polystyrene is convenient for machining. And the most important quality polystyrene is the most resistant to the effects of ionizing radiation as compared to other plastics. Under the action of ionizing radiation, sewing together of polymer chains is possible.

An important component of composite material is powdered aluminum. Conducted research with aluminum powders of different types. Aluminum $\mathrm{AlMg}_{2}$ (ISO 209-1) was used. Also used powder aluminum ASD-6 (TU 1791-007-49421776-2011) [6]. Aluminum has almost no effect on the increase in radiationprotective properties. The presence of aluminum powder creates a matrix that significantly strengthens the base. This is because powdered aluminum has a high surface chemical activity. During the interaction, a maximum bond is reached between the individual 
particles of the aluminum powder and polystyrene. A size of separate grain of aluminum could be $10 \ldots 20$; $30 . .40 ; 60 \ldots 90 \mu \mathrm{m}$.

For radiation protection, powder tungsten PV-2 (TU 14-22-143-2000) was used. The sizes of separate grains of tungsten are $20 \ldots 40 ; 50 \ldots 60 ; 120 \ldots 150 ; 180 \ldots 210$; $230 \ldots 280 \mu \mathrm{m}$.

It is possible to use powder-like steel of A57036 (ST3Sp) (GOST 977-75). The size of separate grains is 230 or $380 \mu \mathrm{m}$. Radiation-protective characteristics are significantly lower than at tungsten. The cost of steel powder is considerably cheaper than cost of powder of tungsten. For making of steel powder used wastes of lathe production [7].

\section{CONDUCTING EXPERIMENTS AND DISCUSSION OF RESULTS}

Improvement of equipment. The manufacture of radiation-protective composite materials was carried out on standard equipment. Used thermoplastic machines Kuasy 100-25, Windsor SP 80. An important feature of this equipment is the ability to manufacture reinforced products from polymers. These thermoplastic machines work according to the same scheme: heating polystyrene to the melting temperature, further extrusion of the desired products into a press (Fig. 1).

In the manufacture of a composite, it is necessary to obtain the maximum homogeneity of the distribution of its components over the volume standard. Technologically, the operation of these thermoplastic apparatuses is well known and perfected. However, in our case it is necessary to obtain a complex composition, which consists of three components. The two components are fine metal powder. Each component has its own heat capacity and thermal conductivity. Under standard conditions, this is a difficult task. Work was carried out to improve the thermoplastic apparatus [8,9].

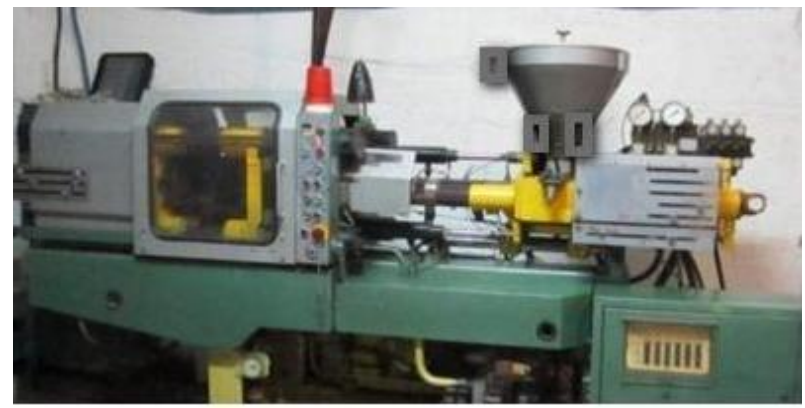

Fig. 1. Photograph of thermoplastic Windsor SP 80 with structural modifications

The block diagram of the improved thermoplastic apparatus is shown in Fig. 2.

The device of the thermoplastic apparatus was complemented the a pre-heating system of the bunker (20). An important addition was the mixing system. It consisted of two independent devices. The blades (21) with the drive (22) produced mixing of the components in the bunker. The drive (24) and the rotator allowed the entire bunker to be rotated in the opposite direction from the blades rotation. Experimentally obtained rotational speeds of the blades for various composites.

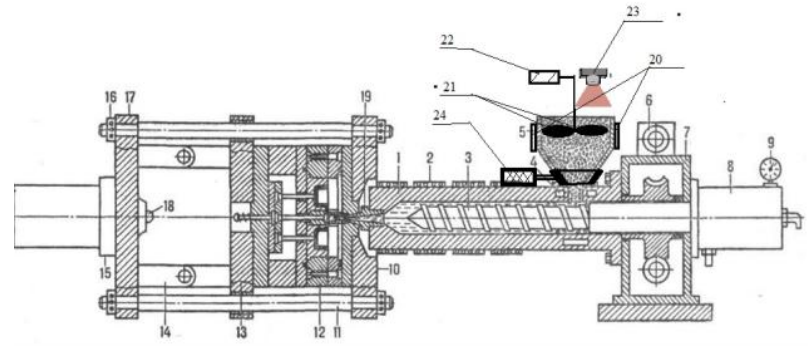

Fig. 2. Of principle chart of castable machine for casting under constraint: 1 -material cylinder;

2 - heating elements; 3 -screw (auger); 4 - cooling channels; 5 -material hopper; 6 - hydraulic engine;

7 - gearbox; 8 -hydraulic cylinder injection unit;

9-manometer; 10, 17 -fixed plates; 11 - guide

columns; 12 - injection mold; 13 - movable plate;

14 - wheel-lever mechanism; 15 - hydro-cylinder of the clamping unit; 16 -nuts; 18 -emphasis; 19 -nozzle;

20 - bunker heaters; 21 - blades for mixing the mixture; 22 - mixer drive; 23 - IR control camera;

24 - drive and rotary device for the entire bunker

The speeds of rotation of the blades when mixing composites (PS-W-AL) (turnovers / minute)

\begin{tabular}{|c|c|c|c|}
\hline $\mathrm{C} 080403$ & $\mathrm{Al}(20 \mu \mathrm{m})$ & $\mathrm{Al}(40 \mu \mathrm{m})$ & $\mathrm{Al}(60 \mu \mathrm{m})$ \\
\hline $\mathrm{W}(30 \mu \mathrm{m})$ & 35 & 31 & 27 \\
\hline $\mathrm{W}(60 \mu \mathrm{m})$ & 32 & 28 & 24 \\
\hline $\begin{array}{c}\mathrm{W} \\
(150 \mu \mathrm{m})\end{array}$ & 29 & 25 & 21 \\
\hline $\begin{array}{c}\mathrm{W} \\
(180 \mu \mathrm{m})\end{array}$ & 22 & 19 & 17 \\
\hline
\end{tabular}

The composite of C080403 was used. The process of his making is most simple. A composite has enough high radiation-protective and considerable strength descriptions. He contains components of tungsten, polystyrene, aluminum. By weight composition: tungsten (W) $-74.7 \%$, aluminum $(\mathrm{Al})-13.95 \%$, polystyrene (PS) $-11.35 \%$. On by volume composition the compo of $\mathrm{C} 080403$ has by volume parts: PS -8 , $\mathrm{W}-4, \mathrm{Al}-3$ from a general volume 15 parts.

IR-radiometric diagnostics of homogeneity of heating. A significant influence on the homogeneity of the composite material has the efficiency of heating the mixture. The various components of the composite have different heat capacity and thermal conductivity. Their heating rate is different. Lumps are formed. Regions with uneven temperature distribution appear. The evenness of heating indicates that polystyrene and the components of the metal components are heated equally. Heating of all components of mixture at its interfusion, allows to get the homogeneous distributing of these components on all volume of mixture. Control of the temperature field on the surface of the mixture is necessary. For the performance of this objective it was suggested to apply a thermal-imaging technique. The production used cameras Lend Ti-814, Fluke-10, Fluke25 [11]. Thermogram of the mixture surface, at the initial stage, are shown in Fig. 3 (composite C080403). 


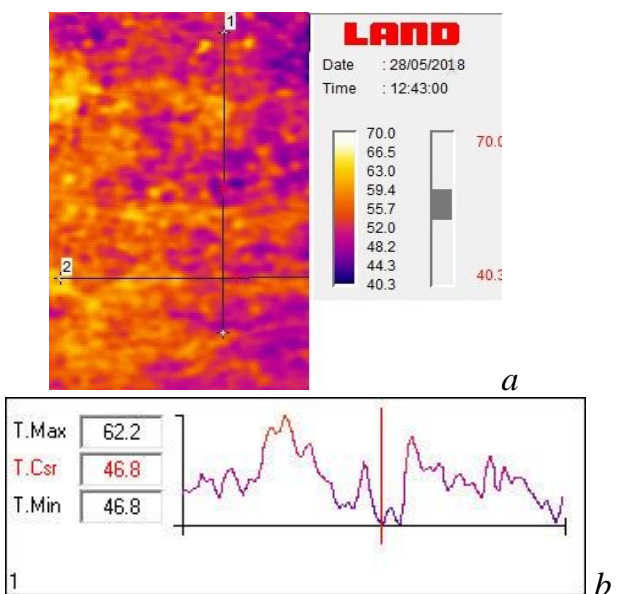

Fig. 3. Photograph of the thermogram of surface of mixture (à) and graphs of change of temperatures along a section $1(b)$

On the thermogram we observe areas with different colors and different intensities. This allows you to identify areas with deviations of the temperature field. All these areas indicate the presence of uneven heating of individual sections. Among them there can be both lumps of aluminum, tungsten and lumps of polystyrene. In the graphs of Fig. 3,b we observe a change in the temperature field in a wide range (up to $20^{\circ} \mathrm{C}$ ). Upon further heating and stirring, the polystyrene melt occurs. Polystyrene uniformly fills the entire space between the particles of the metal component. Temperature equalization occurs in the entire volume of the mixture. In the ideal case, the thermogram of the surface of the mixture has the form (Fig. 4).
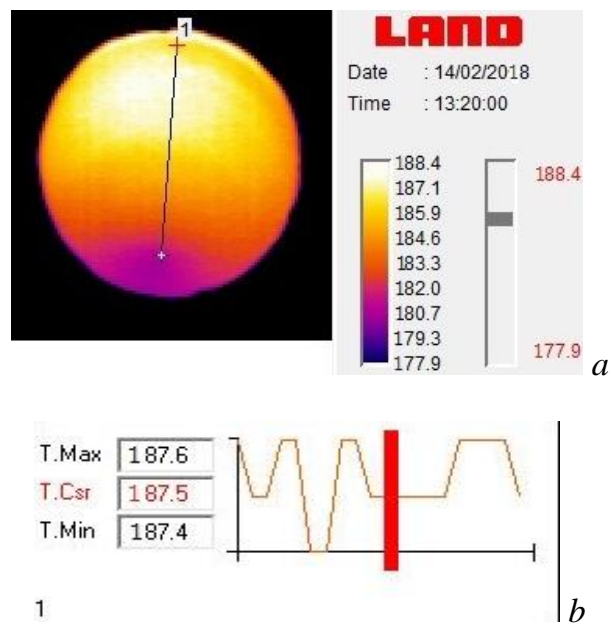

Fig. 4. Photograph of the thermogram of the surface of the mixture (a) and graphs of temperature changes along section $1(b)$

On the graph of temperature changes, their interval is only $0.2^{\circ} \mathrm{C}$ (the temperature is homogeneous).

\section{PERFORM A HARDNESS MEASUREMENT}

Method of measuring hardness. An important parameter that characterizes the properties of composite radiation-protective materials is their strength. On the basis of the known strength of composite materials, the operation time in an aggressive environment, the conditions for their use are determined. The shape and optimal dimensions of the radiation protective layer are found. The strength of the material is a common characteristic. Its definition is directly proportional to hardness. The concept of hardness for polystyrene-metal composite materials differs from the concept of hardness for solids. The concept of hardness for polystyrene-metal composites includes such parameters: a) resilience of composite material residual deformation; b) firmness to pressure in the process of exploitation; c) resistance to penetration deep into the volume. There is a direct relationship between hardness and other characteristics of materials. Therefore, it is necessary to determine the hardness in the study of polystyrenemetal composites.

For finding of hardness of the reinforced polymers or composition materials with the use of polymers there is a row of methods. We are interested in those that are based on the ability of materials to resist the introduction of another body into them. Most often use the methods of Shore (A, D), Barkol, Rockwell (P). In the case of the Shore method and the Barcol method, the depth of penetration into the material of the probe indenter is measured. For materials of different hardness probes of various types are used. In our case, these methods are not entirely effective. This is due to the presence of grains of metal with a size of about $200 \mu \mathrm{m}$ in the composite, which will lead to insufficiently accurate results. The method of Rockwell (P) gives maximal exactness of measurings. The minimum number of measurements is performed. The calculation of hardness is executed by the formula:

$$
H R=130-(H-h) / 0.002,
$$

$h$ - is the depth of penetration of the indenter (ball) under preload; $H$ - is the depth of penetration of the indenter (ball) under the main load. The disadvantage of this method is the conventionality of units of hardness. These units are not tied to physical values. Translation to physical quantities only for certain materials and on the nonlinear spreadsheet. For the measurements used the device NOVOTEST-TP. His analogues are devices of TK-2, TSH-500, HR-1500.

Preparation of Samples. Samples were made for implementation of practical tests. Samples had a different degree of distributing of metallic components on volume $[8,9]$. On a Fig. 5 the type of typical sample.

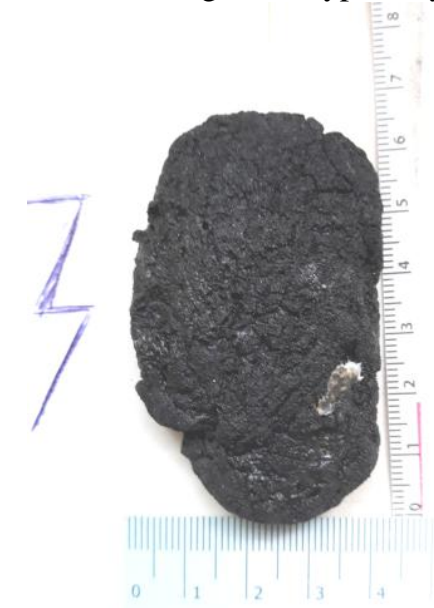

Fig. 5. Original appearance of sample composite material 
Its dimensions are $40 \times 70 \times 15 \mathrm{~mm}$. The choice of such a shape and size depends on the possibility of using these samples in devices to determine the hardness. Composite material C080403 investigated.

Heterogeneities of the two types appear in the manufacture of samples. The first type is heterogeneity, in which the components are arranged in separate lumps, there are gaps, cavities, bubbles. And the second type is heterogeneity, in which the uneven distribution of components on the volume of the composite.

Samples with heterogeneity of not more than $30 \%$ and heterogeneity of not more than $50 \%$ were considered. A photograph of an enlarged image of a sample with a 30\% heterogeneity is shown in Fig. 6.

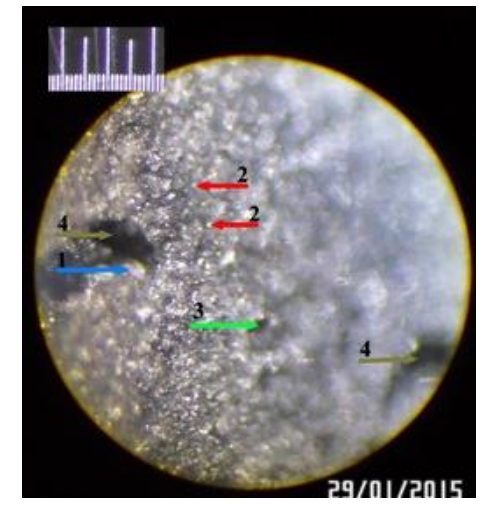

Fig. 6. Photograph of a cut of composite material C080403 with heterogeneity that do not reach 30\%:

1 -tungsten; 2 -aluminum; 3 -polystyrene;

4 - heterogeneities filled with polystyrene

Hardness measurement. We studied four samples with different sizes of grains of components. Samples were selected with heterogeneity of the distribution of components by volume. In the case of polystyrene-metal composites, fabrication uniformity is controlled by changing the shade of grey color. For each sample, hardness measurements were performed at the points where the inhomogeneities in the distribution of the components were observed.

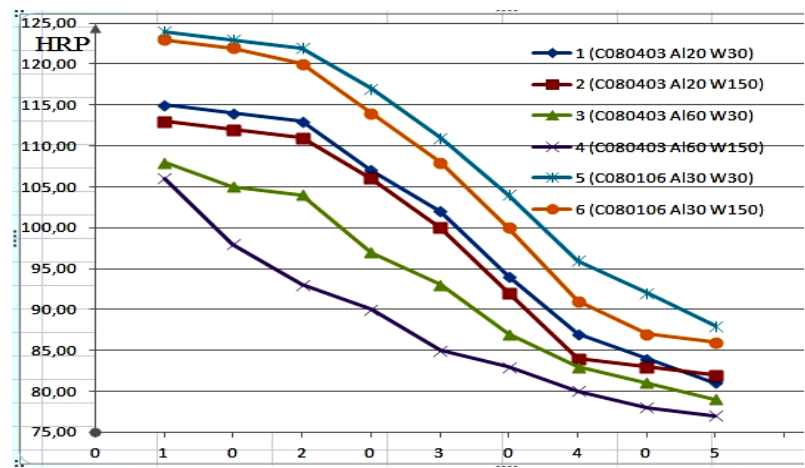

Fig. 7. A graphs of the hardness of composite materials depending on the homogeneity of the distribution of components on volume of the samples

In the graphs of Fig. 7 shows the hardness of composites C080403 and C080106, depending on the homogeneity of the distribution of components. These materials are specifically studied together. They have the same volume of polystyrene. The total volume of the metal component is the same. Composites differ in the amount of tungsten and aluminum. Volumes of tungsten and aluminum are close (C080403). The volume of aluminum is six times the volume of tungsten (C080106). This is important. Measurements were performed for composites with different sizes of grains of components.

At point 1 , hardness values are given for composite materials close to the ideal case. At point 2, the hardness values are given for areas with an insignificant degree of inhomogeneity of the distribution of components (no more than $10 \%)$. At point 3 - heterogeneity reaches $30 \%$. In these areas there is a significant decrease in hardness (strength). Point 4 - heterogeneity can reach $50 \%$. Point 5 - heterogeneity above $50 \%$. We look after the fall-off of hardness. This is especially evident for composites with small sizes of grains of components. It can be seen from the graphs that the strength of composite materials strongly depends on the homogeneity of the distribution of the component material over the sample volume. With the increase of heterogeneity diminishes hardness. This is due to the deterioration of the reinforcement of the radiationprotective composite.

Dependence of hardness was got from the sizes of grains of metallic components. Hardness is increased with diminishing of sizes of grains of metallic components. Composite material (C080403) with minimum of grains sizes (dark blue curve 1, a marker is a rhombus) has maximal hardness. In this composite the following sizes of grains: $\mathrm{Al}-20 \mu \mathrm{m}, \mathrm{W}-30 \mu \mathrm{m}$. The composite (C080403) with the maximum sizes of grains (purple curve 4 , the marker is a rotated cross) has minimal hardness. In this composite, the size of the grains: $\mathrm{Al}-60 \mu \mathrm{m}, \mathrm{W}-150 \mu \mathrm{m}$.

From graphs which are presented on a Fig. 7, another conformity to law follows. There are numeral differences depending on the type of composite material. Curves 5, 6 are higher, than curves 1-4. Curves 5, 6 correspond to hardness of composite material (C080106). Curves 1-4 correspond to the hardness of the composite material (C080403). The composite (C080106) has six parts by volume of aluminum, and the composite (C080403) has three parts by volume. For composites of the group (C080106), we observe the same regularities in the change in hardness as for composites of the group (C080403).

The value of hardness decreases with increasing non-uniformity of the distribution of metal components by volume of the composite material. The value of hardness decreases with increasing grains of metal components. A few features were found out on the basis of analysis of curves 1-6.

Increasing the grains of tungsten has a smaller effect on reducing the hardness value than increasing the grains of aluminum. This is due to the fact that the various metal components of the composite material have a different bond with polystyrene. Tungsten powder is significantly weaker bonded to polystyrene than aluminum powder.

The basic strengthening of the matrix of the composite material occurs due to the connection of polystyrene with aluminum. However, the main task is the creation of radiation-protective matrix composite materials. Therefore, it is necessary to determine the 
necessary hardness and radiation characteristics of composite materials for each specific case. In this case, it is necessary to observe a certain balance between the hardness of the composite material and its radiationprotective properties.

Calculation of radiation-protective characterristics. Effective use of polymer-metal composite materials is impossible without knowledge of their radiation-protective properties. Measurement of these characteristics is a difficult task [11]. To determine the radiation protective properties, we use the results of calculations. Currently developed and widely used several packages for the calculation of protective properties. In our work, the package Geant4 v 4.9.6p03 [12] was used.

We obtain the results of radiation protection. In these calculations, the effect of ionizing radiation on a biological phantom was considered. The basic parameter of efficiency of defence is the relative weakening of ionizing radiation dose.

This parameter is calculated on a mathematical formula:

$$
\eta=1-\frac{D}{D_{\text {air }}}
$$

In expression (2), the parameter $D_{\text {air }}-$ is the calculated dose, in the absence of protection. Parameter $D$ - is the calculated dose when protected. The parameter $\eta-$ is the degree of relative attenuation of the absorbed dose of gamma-radiation by a layer of protection made of a composite material. Graphs of relative attenuation of the absorbed dose were obtained (Fig. 8).

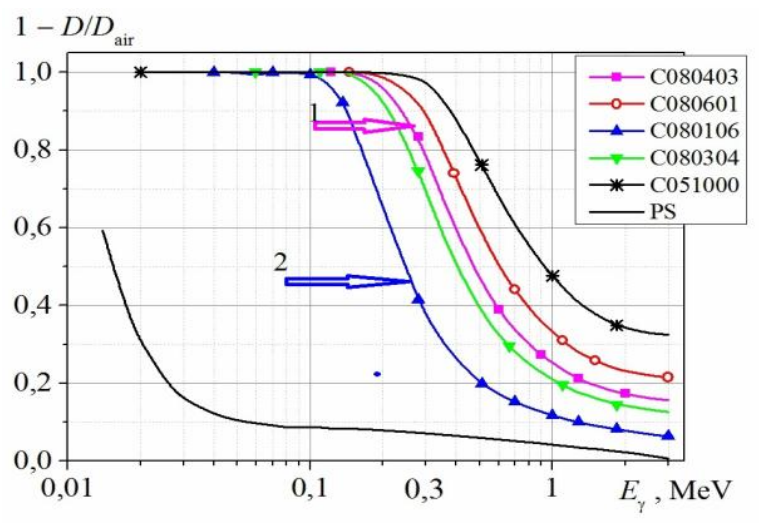

Fig. 8. Dependence of the relative weakening of the eaten up dose on the energy of gamma-quanta

In the calculations, we used the approximation of an ideal composite material. By ideality we mean the homogeneity of the distribution of components by volume and the absence of cavities. The weakening of the dose of the composite material (C080403) is indicated by a purple curve (the marker is square). The dose attenuation by composite material (C080106) is indicated by a blue curve (a marker is a triangle). The weakening by the composite (C080106) is significantly weaker than the weakening by the composite (C080403). Thus, the half-attenuation for C080106 is already achieved at gamma-quanta energies of $300 \mathrm{keV}$. Whereas the half attenuation for the composite (C080403) is achieved only at energies of $600 \mathrm{keV}$. The use of $\mathrm{C} 080403$ is more effective than $\mathrm{C} 080106$.
Although in terms of its strength characteristics, C080106 is 9\% higher than C080403.

The study of the hardness (strength) of a composite material, depending on the degree of heterogeneity of the distribution of components across its volume, allows solving several problems. One of them is a decline of requirements on quality of making. This requirement immediately allows you to make cheaper the cost of composite materials, increase the profitability of their production and increase production speed.

\section{CONCLUSIONS}

1. In the work, the characteristics of the hardness of polystyrene-metal composite materials are investigated at various degrees of homogeneity of the distribution of components on volume sample.

2. The constructional refinements of industrial thermoplastic automata, which allow the production of composite materials of polystyrene and metal, are shown.

3. For several types of composite materials experimentally selected modes of operation of additional devices.

This allows to increase the uniformity of the distribution of the composite components in its volume.

4. The technology of thermographic quality control of mixing the components of the composite material has been refined.

5. From the got graphs of the temperature field and thermograms, the characteristic features of display of violations of the homogeneity of raw materials for the production of composite materials are determined.

6 . The results obtained on the basis of the analysis of the work: a) with increasing in homogeneity of composites decreases hardness; b) hardness increases with decreasing particle size components of the mixture; c) aluminum particles play a crucial role in the formation of the volume structure of the composite material.

\section{REFERENCES}

1. V.N. Gulbin. Development of the composite materials modified by nano powders, for radiation protection in atomic engineering // Nuclear physics and engineering. 2011, v. 2, N 3, p. 272-286

2. E.M. Prohorenko, A.A. Zaharchenko, A.I. Scrypnyk, M.A. Hazhmuradov, V.F. Klepikov, V.V. Lytvynenko. Improving of characteristics of composite materials for radiation biological protection // Problems of Atomic Science and Technology. 2013, N 6(88), p. 240-243.

3. E.M. Prokhorenko, V.F. Klepikov, V.V. Lytvynenko, A.A. Zaharchenko, M.A. Hazhmuradov. Metal containing composition materials for radiation protection // Problems of Atomic Science and Technology. 2014, N 4(92), p. 125-129.

4. V.F. Klepikov, E.M. Prokhorenko, V.V. Lytvynenko, S.E. Donets, V.N. Robuk, T.G. Prokhorenko, V.T. Uvarov, A.G. Ponomarev, Yu.F. Lonin. The use of high-current relativistic electron beams for the study of the effects of ionizing radiation on materials storage RAW // Problems of Atomic Science and Technology. 2016, N 2(102), p. 72-77. 
5. V.F. Klepikov, E.M. Prokhorenko, V.V. Lytvynenko, A.A. Zaharchenko, M.A. Hazhmuradov. Application of methods of mathematical modeling for determining of radiation-protective characteristics of polystyrene-metal composite materials // Problems of Atomic Science and Technology. 2016, N 3(103), p. 123-127.

6. V.V. Bryukhovetskiy, N.I. Bazaleev, V.F. Klepikov, V.V. Litvinenko, O.E. Bryukhovetskay, E.M. Prokhorenko, V.T. Uvarov, A.G. Ponomar'ov. Features of gelation of surface of industrial aluminium alloy 6111 in the area of influence of impulsive bunch of electrons in the mode of premelting // Problems of Atomic Science and Technology. 2011, N 2(72), p. 28-32.

7. E.M. Prokhorenko, V.F. Klepiakov, V.V. Lytvynenko, P.A. Khaymovich, N.A. Shul'gin, A.I. Morozov. Diagnostics of processes of wear of materials of balls drum mills // Eastern European Journal of Enterprise Technologies. 2015, N 1/5, v. 73, p. 14-20.

8. V.F. Klepikov, E.M. Prokhorenko, V.V. Lytvynenko, A.A. Zaharchenko, M.A. Hazhmuradov. Control of macroscopic characteristics of composite materials for radiation protection // Problems of Atomic Science and Technology. 2015, N 2(96), p. 193-196.

9. V.F. Klepikov, E.M. Prokhorenko, V.V. Lytvynenko, A.A. Zaharchenko, M.A. Hazhmuradov. Performance ratio hardness characteristics polystyrenemetal composite materials // Problems of Atomic Science and Technology. 2015, N 5(99), p. 36-42.

10. E.M. Prohorenko, V.F. Klepikov, V.V. Lytvynenko, N.I. Bazaleyev, I.I. Magda, T.G. Prohorenko, A.I. Morozov. Application of ir-radiometric diagnostics for control of vacuum connections of electrophysical installations // Problems of Atomic Science and Technology. 2018, N 1(113), p. 212-217.

11. A.I. Scrypnyk, A.A. Zakharchenko, M.A. Khazhmuradov, E.M. Prokhorenko, V.F. Klepikov, V.V. Lytvynenko. Simulation of Characteristics of Gamma-Radiation Detectors Based on Mercury Compounds // Problems of Atomic Science and Technology. 2013, N 3(85), p. 231-235.

12. J. Allison, K. Amako, J. Apostolakis, H. Araujo, et al. Geant4 developments and applications. // IEEE Transactions on Nuclear Science. 2006, v. 53, p. 270-278.

\title{
ИЗУЧЕНИЕ ИЗМЕНЕНИЯ ХАРАКТЕРИСТИК РАДИАЦИОННО-ЗАЩИТНЫХ КОМПОЗИЦИОННЫХ МАТЕРИАЛОВ В ЗАВИСИМОСТИ ОТ ОДНОРОДНОСТИ РАСПРЕДЕЛЕНИЯ МЕТАЛЛИЧЕСКИХ КОМПОНЕНТ
}

\author{
Е.М. Прохоренко, В.В. Литвиненко, А.А. Захарченко, М.А. Хажжмурадов, Т.Г. Прохоренко
}

\begin{abstract}
Исследована зависимость твердости полистирол-металлических композиционных материалов от однородности распределения частиц компонент по объему композиционного материала. Предложены усовершенствования термопластавтоматов, которые позволяют повысить качество изготовления композитов. Доработаны методики ИК-радиометрической диагностики эффективности перемешивания компонент. Опытным путем определены скорости лопастей смесителя в зависимости от размеров и количества частиц металлических компонент. Для конкретных композиционных материалов численными методами получены радиационно-защитные характеристики. Проанализировано ослабление поглощенной дозы ионизирующего излучения в зависимости от энергии гамма-квантов.
\end{abstract}

\section{ВИВЧЕННЯ ЗМІН ХАРАКТЕРИСТИК РАДІАЦІЙНО-ЗАХИСНИХ КОМПОЗИЦЙНИХ МАТЕРІАЛІВ У ЗАЛЕЖНОСТІ ВІД ОДНОРІДНОСТІ РОЗПОДІЛУ МЕТАЛІЧНИХ КОМПОНЕНТ}

\section{С.М. Прохоренко, В.В. Литвиненко, О.О. Захарченко, М.А. Хажсмурадов, Т.Г. Прохоренко}

Досліджено залежність твердості полістирол-металевих композиційних матеріалів від однорідності розподілу часток компонент за об'ємом композиційного матеріалу. Запропоновано удосконалення термопластавтоматів, які дозволяють підвищити якість виготовлення композитів. Доопрацьовані методики ІЧ-радіометричної діагностики ефективності перемішування компонент. Дослідним шляхом визначено швидкості лопатей змішувача, в залежності від розмірів і кількості частинок металевих компонент. Для конкретних композиційних матеріалів чисельними методами отримані радіаційно-захисні властивості. Проаналізовано ослаблення поглиненої дози іонізуючого випромінювання в залежності від енергії гаммаквантів. 